\title{
Morphological Characterization and Pathogenicity of Oidium mangiferae on Mango
}

\author{
Lovepreet $\operatorname{Kaur}^{1,2} *$ \\ ${ }^{1}$ Department of plant pathology, Dr. Y.S. Parmar University of Horticulture and Forestry, \\ Nauni- 173230, India \\ ${ }^{2}$ Chandigarh University, Gharuan, Mohali- 140413, India \\ *Corresponding author
}

\section{A B S T R A C T}

Keywords

Oidium mangiferae,

Mango,

Pathogenicity,

Morphology

Article Info

Accepted:

12 April 2019

Available Online:

10 May 2019
Samples of powdery mildew of mango collected from the different areas of Himachal Pradesh revealed the absence of cleistothecia. On the basis of anamorphic characters like presence of abundant, hyaline, barrel- shaped to ellipsoid and single celled conidia produced singly or in chains of two to four, germinating conidia produced simple germ tubes, Superficial, hyaline and septate mycellium. The fungus inciting the disease was identified as Oidium mangiferae. In the pathogenicity tests during April on one year old grafted mango cv. Dusheri, symptoms appeared after 8 days and 5 hours of inoculation on leaves whereas on pedicels symptoms appeared after 10 days and 20 hours.

\section{Introduction}

Mango is universally considered one of the most important fruit crop. Mango is attacked by number of diseases. Powdery mildew caused by Oidium mangiferae is one of the most serious diseases of mango. The disease usually manifest during January to March (flowering time) but at elevation of 600 to 1200 meters a.m.s.l. is known to persist for longer periods (Palti et al., 1974). Howard et al., (1994) revealed that powdery mildew pathogen usually attacks the young tissue of all parts of the inflorescences, leaves and fruits. Initially small isolated patches of powdery white mycelium develops on the affected organs. These coalesce later to grow in size and cover both sides of the leaf, petioles and young stems. The mildew attacks mango flowers before fertilization and results in the dropping of unfertilized flowers. Young fruits may entirely get covered by the mildew. As the fruit grows, its epidermis in the infected areas develops cracks and later formation of corky tissue lead to their premature dropping at pea size (Kulkarni, 1924). Palti et al., (1974) reported that penetration of pathogen is restricted to the 
epidermal layers of the infected parts. Fungal development ceases when infected tissues become necrotic. Crop loss from powdery mildew of mango mainly results from blossom infection. Infected flowers fail to open and drop.

\section{Materials and Methods}

\section{Identification and pathogenicity of causal fungus}

\section{Identification}

Mango leaves and fruits with typical symptoms of powdery mildew disease were collected during disease survey. Morphological characteristics of mycelium, conidiophores and conidia of the fungus were recorded by extracting them from the diseased samples with the help of needle. The microscopic observations were taken by placing them on glass slides under light microscope (Magnus). The observations on shape, septation and number of conidia in a chain as well as size of conidia in terms of length and breadth were recorded with the help of computer software (Magnus MIPS: Micro Image Projection System). These observations were compared with already published accounts of Jhooty et al., (1983) to confirm the identity of the organism. Microphotographs of the conidia, conidial chains and germ tubes were also taken.

\section{Pathogenicity test}

Koch's postulates were established to prove the pathogenicity of causal fungus. Pathogenicity of fungus was conducted under laboratory condition following leaf inoculation method.

\section{Under laboratory conditions}

One year old grafted plants of mango cv. 'Dusheri' were planted in the plastic pots $(8 \mathrm{x}$ 12 inches). The newly emerged leaves in the month of April were surfaced sterilized by spraying sodium hypochlorite solution $(1.0 \%)$ and after 20 minutes of spray leaves were washed thoroughly with sterilized water thrice. The conidial suspension of powdery mildew fungus was prepared in sterilized distilled water $\left(3.2 \times 10^{4}\right.$ conidia $\left./ \mathrm{ml}\right)$ from the diseased samples collected from the field. A sticker Triton was added in the already prepared conidial suspension @ 0.2 per cent and sprayed on the leaves with the help of atomizer. These plants were kept in the growth chamber at an ideal conditions (temperature of $25 \pm 1{ }^{\circ} \mathrm{C}$ and $65 \% \mathrm{RH}$ ) to develop the disease. In another experiment, the plants were covered with polythene bags and the leaves were regularly observed for the development of disease symptoms to calculate the incubation period. The conidia of the fungus were re-isolated and applied on the young fully expanded leaves to prove the Koch postulates.

\section{Results and Discussion}

\section{Identification}

The identification of the causal organism of powdery mildew was done on the basis of morphological characters as given in Table 1.

The microscopic examination of the fungus revealed abundant, hyaline, barrel- shaped to ellipsoid and single celled conidia produced singly or in chains of two to four (Plate 1). The size of the conidia ranged from $31.25-$ $44.79 \times 16.50-23.11 \mu \mathrm{m}$. The mycelium of the fungus was superficial, septate, hyaline measuring 3.8 to $7.9 \mu \mathrm{m}$.

In the present investigation, the microscopic examination of the associated fungus with diseased samples collected during survey of the different localities indicated that abundant, hyaline, barrel shaped to ellipsoid to ovoid, single celled conidia were produced either singly or in the chains of two, three or 
four on hyaline, two to four celled, clavate conidiophores. Size of conidia and conidiophores ranged between 31.25 to 44.79 $\mathrm{x} 16.50$ to $23.11 \mu \mathrm{m}$ and 63.54 to $163.08 \mu \mathrm{m}$, respectively. The conidia germinated mostly from the terminal end but rarely from the sides producing a single, hyaline germ tube. Jhooty et al., (1983) had established similar dimensions of conidia i.e. 31.57 to $45.92 \mathrm{x}$ 20.09 to $22.96 \mu \mathrm{m}$ and attempted to assign the name of the associated fungus as
Microsphaera alphitoides f. sp. erysiphe in place of Oidium mangiferae based on the morphology of conidiophores and conidia. However, Prakash and Srivastava (1987) reported that conidiophores emerging from the superficial mycelium were 64 to $163 \mu \mathrm{m}$ long and borne unicellular, hyaline, elliptical conidia at their ends with very variable size but more frequently measured 33 to $43 \mu \mathrm{m}$ in length and 18 to $22 \mu \mathrm{m}$ in width, preferred to retain the name Oidium mangiferae Berthet.

Table.1 Morphological characters of powdery mildew causing fungus Oidium mangiferae

\begin{tabular}{|l|c|c|}
\hline Fungal structure & Shape & Size ( $\boldsymbol{\mu m})$ \\
\hline Mycelium & Superficial, hyaline and septate & 3.8 to 7.9 \\
\hline Conidia & $\begin{array}{c}\text { Barrel shaped to ellipsoid - ovoid, single } \\
\text { celled produced in chains of two to four }\end{array}$ & $\begin{array}{l}31.25 \text { to } 44.79 \times 16.50 \text { to } \\
\end{array}$ \\
\hline
\end{tabular}

Table.2 Pathogenicity of $O$. mangiferae causing powdery mildew on mango

\begin{tabular}{|c|c|}
\hline Plant parts & Incubation periods $(\mathrm{hrs})$ \\
\hline Leaves & $197(8$ days and $5 \mathrm{hrs})$ \\
\hline Pedicel & $260(10$ days and $20 \mathrm{hrs})$ \\
\hline
\end{tabular}

\section{Plate.1}

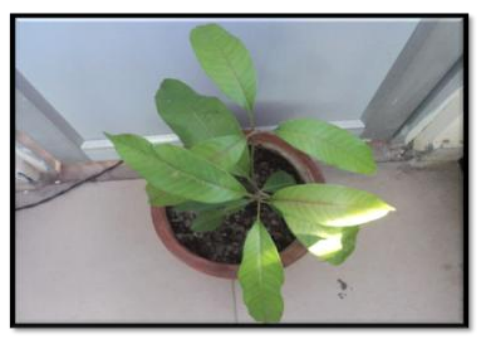

Healthy Plant

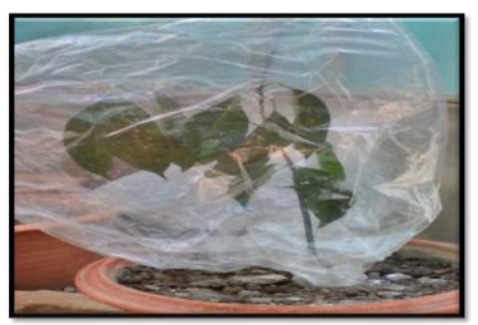

Inoculated Plant

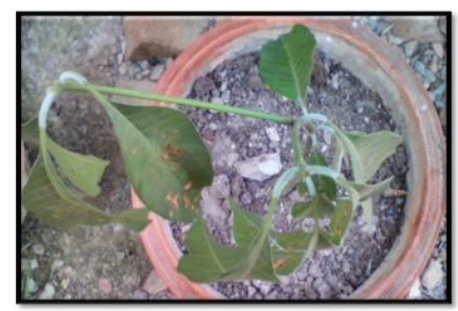

Appearance of Symptoms

Plate1. Pathogenicity Of Oidium mangiferae 
Since, the morphology and dimensions of both the conidiophores and conidia, observed in the present investigations also resembled to those as documented by earlier workers and moreover no cleistothecia could be located. Hence, the name of the pathogen was retained as Oidium mangiferae Berthet.

\section{Pathogenicity test}

The pathogenicity test of powdery mildew fungus $O$. mangiferae was conducted on newly emerged leaves and pedicel of one year old grafted plants of mango cv. 'Dusheri' and Koch's postulates were proved. Symptoms on leaves and pedicels were noticed after $197 \mathrm{hrs}$ ( 8 days and $5 \mathrm{hrs}$ ) and $260 \mathrm{hrs}$ (10 days and $20 \mathrm{hrs}$ ), respectively, of inoculation under the pot conditions in the laboratory (Table 2) and (Plate 1).

In the pathogenicity tests, symptoms appeared after 8 days and 5 hours of inoculation on leaves whereas on pedicels symptoms appeared after 10 days and 20 hours. Adikaram et al., (2002) also calculated the incubation period to the tune of 10-11 days for $O$. mangiferae on Pedilanthus tithymaloides var. caculatus. Similarly, Iliyukhin and Nikitana (1980) reported the incubation period of 5 to 7 days for powdery mildew on okra and 12 days in case of powdery mildew on apple (Kaspers, 1967).

In conclusion, the fungus was of barrel to ellipsoid - ovoid shape, single celled conidia produced in chains of two to four and mycelium was superficial, hyaline and septate. Newly emerged leaves were found to be more susceptible to the infection. It clearly establishes the involvement of $O$. mangiferae as the causal agent of this disease in Himachal Pradesh.

\section{References}

Adikaram N K B, Manilewa G and Weerahewa D. 2002. Changes in pigment composition and metabolism, etc. in Pedilanthus tithynaloides leaf following powdery mildew infection. J. Nati. Sci. Foundation Sri Lanka. 3(2): 91-111

Howard R J, Garland J A and Seaman W L. 1994. Diseases and pests of vegetables crops in Canada: an illustrated compendium. The Canadian Phytopathological Society, Ottawa, Canada. Pp. 1-10.

Iliyukhin G P and Nikitnia M A. 1980. Powdery mildew of cucumber undercover. Phytopatho.19:49-51.

Jhooty J S, Kaur J and Munshi G D. 1983.Identify of powdery mildew of Jujuba and mango. Trop. Pl. Sci. Res. 1: 267-268

Kaspers H. 1967. A contribution to studies on the biology and control of mildew (Podosphaera leucotricha) (Ell. And Ev.) Salm. Pflanzenschuts Naehrichten Bayer. 20: 687-702.

Kulkarni G S. 1924. Report of work done in Plant Pathology section during the year 1922-23. Annual Report Agriculture. Pp. 23: $167-71$.

Palti J, Pinkas Y and Chorin M.1974. Powdery mildew of mango. Plant Dis.Reptr. 58: 45-49.

Prakash O M and Shrivastava K C. 1987. Mango diseases. In: Mango diseases and their management. Today and tomorrow's printers and publishers, New Delhi. 121 Pp.

\section{How to cite this article:}

Lovepreet Kaur. 2019. Morphological Characterization and Pathogenicity of Oidium mangiferae on Mango. Int.J.Curr.Microbiol.App.Sci. 8(05): 1297-1300.

doi: https://doi.org/10.20546/ijcmas.2019.805.148 